\title{
FAKTOR PERAN PERAWAT DALAM PENGISIAN BERKAS REKAM MEDIS DI RUMAH SAKIT HARUM SISMA MEDIKA JAKARTA TIMUR
}

\author{
Alpi Cintya ${ }^{1}$, Diana Barsasella ${ }^{2}$ \\ ${ }^{1}$ Alumni Program Studi S1 Kesehatan Masyarakat STIKes Persada Husada Indonesia \\ ${ }^{2}$ Dosen Program Studi DIII PIKES Poltekkes Kemenkes Tasikmalaya \\ 1barsasella@yahoo.com, 2alpic@ymail.com
}

\begin{abstract}
Medical Recordis necessarythingtonote, many roles ofmedical personnelwhoare veryinfluentialin theMedical Recordfilefilling. One of the roleis thenurse's role, becausenurseismedical professionalwhomoreoftencontact withthe patientthan doctor. Types ofthis research isquantitative, and subject of research are nurses from the entire roomat RumahSakitHarumSismaMedikaJakartaTimur. Theresearch wasconducted inApril-May2012 in Jakarta. TotalPopulationsare 100 people and Samples are117respondents. Resultshowedthat there is no significant relationship between independent and dependent variablesbecausethe knowledgeandskill ofrespondents are already good. Incompletedata of 42.91\% were found during January-March 2012. Theresults of Medical Records Quality were amounted that $56 \%$ of respondentsweregood and $43 \%$ of respondents were not good. Result of Bivariateanalysis that there are significant relationshipbetweenknowledgeandmedical record qualitywiththe p-value of 0.027. The assessment resultsforrespondent knowledgeof medical record quality wereobtained $50 \%$ good knowledge and $50 \%$ bad knowledge, theresults ofrespondent skills wereobtained $68 \%$ good skill and 32\% bad skill. Based on theresearch results, medical recordsteam andthe headof nursing atRumahSakitHarumSismaMedikaEast Jakartaare expected toprovidemoretrainingto nurses from entire room includedhead room and attending nurse.
\end{abstract}

Key words: quality, medical record

\begin{abstract}
Abstrak
Rekam Medis merupakan hal yang sangat perlu diperhatikan, banyak peran tenaga medis yang sangat berpengaruh dalam pengisian berkas Rekam Medis. Salah satunya adalah peran perawat, karena perawat adalah tenaga medis yang sangat sering bersentuhan dengan pasien selain dokter. Jenis penelitian kuantitaif dengan subjek penelitian adalah para Perawat seluruh ruangan di RS Harum Sisma Medika Jakarta Timur. Proses penelitian ini telah dilakukan pada bulan April-Mei 2012 di Kota Jakarta. Jumlah Populasi 117 dan Sampel 100 responden. Hasil penelitian menunjukkan antara variabel independen dan dependen tidak terjadi hubungan yang bermakna atau signifikan dikarenakan dari segi pengetahuan dan keterampilan responden diketahui sudah baik. Didapat angka tidak lengkapnya data selama bulan Januari-Maret tahun 2012 sebesar 42,91\%, dan dengan hasil Mutu Rekam Medis berjumlah 56\% responden yang baik dan 43\% responden yang kurangbaik. Dan dari penghitungan Bivariat diperoleh adanya hubungan yang bermakna atau siginifikan antara pengetahuan dan mutu rekam medis dengan p-value 0,027 . Hasil penilaian dari pengetahuan responden terhadap mutu rekam medis diperoleh hasil $50 \%$ berpengetahuan baik dan $50 \%$ berpengetahuan buruk, sedangkan pada keterampilan diperoleh hasil sebesar $68 \%$ responden memiliki keterampilan baik dan 32\% memiliki keterampilan buruk. Berdasarkan hasil penelitian, maka pihak rekam medis dan kepala keperawatan di Rumah Sakit Harum Sisma Medika Jakarta Timur diharapkan bisa memberikan pelatihan secara lebih kepada petugas perawat diseluruh ruangan termasuk kepala ruangan dan perawat jaga.
\end{abstract}

Kata kunci: mutu, rekam medis 


\section{PENDAHULUAN}

Negara seperti Cina yang Kedokteran umumnya menjadi besar karena mencatat secara medis secara rinci tentang pengalamannya, prosesnya, peningkatan mutu, mengolah data informasinya. Sedangkan di Indonesia yang pengolahan data rekam medis untuk menjadi perencanaan jangka panjang adalah tidak banyak, kita terlalu terlena terhadap sesuatu yang rutin, biasa-biasa saja dan hanya mencatat yang seperlunya saja. Kita menjadi bangsa yang kurang produktif tentang pencatatan karena 3 hal yaitu (1) menganggap sesuatu yang rutin, (2) sikap yang menunggu perintah dan (3) mengandalkan asistensi yaitu menunggu bantuan orang lain. Jangan hanya diam tapi harus proaktif dan harus berbasiskan teknologi informasi jangan manual.

Peningkatan kualitas pelayanan Rumah Sakit pada saat ini sangat penting untuk dilakukan, pada tahun 2010 jumlah Rumah Sakit di Indonesia sebanyak 1.523 dengan jumlah tempat tidur sebanyak 210.000 (Profil kesehatan Indonesia Tahun 2010), dan salah satu upaya untuk mencapai Indonesia Sehat tahun 2010 adalah upaya untuk meningkatkan dan memelihara pelayanan kesehatan yang bermutu, merata dan terjangkau. Munculnya transformasi paradigma rekam medis dari tradisional menjadi manajemen informasi kesehatan pada pertengahan tahun 1990-an merupakan reformasi baru di bidang informasi kesehatan yang dipicu oleh modernisasi perkembangan teknologi informasi dan komunikasi.

Rekam Medis merupakan bukti tertulis tentang proses pelayanan yang diberikan oleh dokter dan tenaga kesehatan lainnya kepada pasien dalam rangka penyembuhan pasien, rekam medis mencantumkan nilai administrasi, legal, finansial, riset, edukasi, dokumen, akurat, informatif dan dapat dipertanggung jawabkan Rekam Medis harus dibuat secara tertulis, lengkap dan jelas atau secara elektronik. Penyelenggaraan Rekam Medis dengan menggunakan teknologi informasi elektronik diatur lebih lanjut dengan peraturan tersendiri. Kegunaan Rekam Medis di Rumah Sakit yaitu berupa aspek administrasi, aspek medis, aspek hukum, aspek keuangan, aspek penelitian. Laporan rumah sakit meliputi: Laporan internal Rumah Sakit (disesuaikan dengan kebutuhan rumah sakit), Laporan eksternal Rumah Sakit yang dilaporkan pada Kementerian Kesehatan RI dan Dinas Kesehatan Provinsi serta Dinas Kesehatan Kabupaten/Kota. Periode pelayanan eksternal yaitu bulanan, tri bulanan dan tahunan.
Didalam pengisian berkas rekam medis sangat berpengaruh dengan Mutu rekam medis di Rumah Sakit tersebut, terutama dalam pembagian tugas pengisian rekam medis oleh petugas rekam medis. Mutu adalah perpaduan sifat-sifat dan karateristik pemakai atau pelanggan. Deming (1980) mengemukakan bahwa mutu dapat dilihat dari aspek konteks, persepsi pelanggan, serta kebutuhan dan keinginan peserta. Penyebab yang terjadi dari suatu masalah mutu selalu menitikberatkan kepada manusia (karyawan). Pandangan terhadap masalah mutu pelayanan seperti ini disebabkan karena kurangnya minat atau perhatian karyawan. Maka yang sering diangkat adalah bagaimana staf/karyawan dibuat lebih peduli terhadap peningkatan mutu pelayanan. Pemantauan seperti ini guna mencegah konsumen atau pasien atau masyarakat memperoleh pelayanan kesehatan yang tidak memenuhi standar yang sudah ditetapkan.

Peneliti melakukan penelitian ini di Rumah Sakit Harum Sisma Medika Jakarta Timur sesuai dengan visi RS Harum Sisma Medika "Pusat Rujukan Alternative Bidang Pelayanan Kesehatan Bagi Masyarakat Jakarta Timur Dan Sekitarnya”. Didalam pelayanan kesehatan Rumah Sakit ini mengutamakan pelayanan terbaik untuk pasien yang datang. Bertitik tolak dengan pengertian diatas hasil pengamatan selama bulan januari-maret tahun 2012 ini terdapat hambatan, karena: 1. Pengisian yang tidak lengkap, dimana terdapat angka ketidaklengkapan 42, 91\% dari jumlah pasien selama bulan Januari-Maret 895 orang sejumlah 384 orang. 2. Pengembalian tidak tepat waktu, ini diakibatkan karena rekam medis tadi belum terisi lengkap dan terhambat disaat melakukan pengisian sehingga pengembalian Rekam Medis terlambat.3. Keakuratan, dimana kebenaran dalam pengisian berkas rekam medis di dalam dokumen berpengaruh dalam penggunaan berkas rekam medis jika diperlukan 4. Memenuhi aspek hukum yang dikaitkan dengan lengkap dan akuratnya dalam pengisian Rekam Medis, setelah selesai melakukan pengisian maka petugas pengisi Rekam Medis wajib memberikan tanda tangan yang di anggap sah dan memenuhi aspek hukum.

Alasan penelitian ini diadakan terutama kepada petugas perawat adalah kebanyakan penelitian dilakukan kepada dokter, dikarenakan dokter tidak terlalu teliti dalam pengisian berkas rekam medis,penulis tertantang meneliti cara kinerja perawat dalam pengisian berkas rekam medis itu dikarenakan masih banyaknya fakta dilapangan bahwa pengetahuan 
dalam rekam medis belum sepenuhnya diketahui. Sehinggapenulistertarikuntukmenelitifaktor perawat dalam pengisian berkas Rekam Medis terhadap mutu Rekam Medis di Rumah Sakit Harum Sisma Medika Jakarta Timur.

\section{METODE}

Penelitian ini merupakan penelitian kuantitatif untuk mengetahui faktor Peran Perawat dalam pengisian berkas rekam medis terhadap mutu rekam medis di Rumah Sakit Harum sisma Medika Jakarta Timur dengan penelitian yang digunakan adalah cross sectional (potong lintang), dengan metode deskriptif korelasi, hal ini dikarenakan pengukuran variabel bebas dengan variabel terikat dilakukan dengan waktu yang sama.

Populasi penelitian adalah semua perawat yang bertugas di Rumah Sakit Harum Sisma Medika Jakarta Timur. Sampel adalah sebagai bagian dari populasi yang menjadi objek penelitian (Imron,2010). Dalam penelitian ini peneliti mengambil objek seluruh petugas perawat yang bekerja di Rumah Sakit Harum Sisma Medika Jakarta Timur. Dari populasi yang ada, sampel penelitian berjumlah 100 responden.

Dalam penelitian ini semua tenaga perawat adalah responden, karena jumlah perawat bekerja di Rumah Sakit Harum Sisma Medika Jakarta Timur yang tidak terlalu banyak yaitu 100 perawat sehingga akan lebih akurat jika semua perawat dijadikan responden.

Pengelolaan data dilakukan dengan cara menggunakan program SPSS Versi 17, maka dari itu perlu dilakukan Editing Data, Coding Data, Entry Data, danCleaning Data.Metodeanalisis data dengan: Analisis UnivariatdanAnalisisBivariat. Analisis statistic bivariat mengunakan Chi-Square yaitu: untuk mengetahui hubungan antara variabel independen dan variabel dependen.

\section{HASIL}

\section{Gambaran Karateristik}

Karakteristik responden dalam penelitian ini terdiri dari jenis kelamin, usia dan masa kerja.Berdasarkan tabel 1 dibawah, jenis kelamin perawat yang bekerja di Rumah Sakit Harum Sisma Medika ini paling banyak adalah perempuan dengan persentase (95\%).
Untuk Usia perawat yang mencapai (67\%) adalah usia dari $<25$ Tahun -30 Tahun. Untuk lama masa kerja perawat di Rumah Sakit Harum Sisma Medika ini terbanyak ada dalam masa kerja $<3-5$ Tahun sebesar (54\%), dan persentase terendah (36\%) adalah 5 - 10 Tahun masa kerja.

Tabel 1. Distribusi Karakteristik Responden Menurut Jenis Kelamin, Usia, Masa Kerja Perawat di Rumah Sakit Harum Sisma Medika Jakarta Timur Tahun 2012

\begin{tabular}{lcc}
\hline \multicolumn{1}{c}{ Pertanyaan } & Jumlah & Persentase \\
\hline Jenis Kelamin & 5 & \\
1. Laki- Laki & 95 & $5 \%$ \\
2. Perempuan & & $95 \%$ \\
\hline Usia & 67 & $67 \%$ \\
1. $<30$ Tahun & 34 & $34 \%$ \\
2. $>30$ Tahun & & \\
\hline Masa Kerja & 54 & $54 \%$ \\
1. $<5$ Tahun & 36 & $36 \%$ \\
2. $>5$ Tahun & & \\
\hline
\end{tabular}

\section{Gambaran Pengetahuan}

Gambaran pengetahuan responden diukur menggunakan delapan pertanyaan.Berikut adalah rincian jawaban responden dapat dilihat pada tabel 2 .

Tabel 2. Distribusi Pertanyaan dan Jawaban Pengetahuan Responden Tentang Rekam Medis

\begin{tabular}{lcc}
\hline \multicolumn{1}{c}{ Pertanyaan } & Jumlah & Persentase \\
\hline $\begin{array}{l}\text { Pengertian Umum Rekam } \\
\text { Medis }\end{array}$ & \\
1. Salah & 67 & $67 \%$ \\
2. Benar & 33 & $33 \%$ \\
\hline Fungsi Utama Rekam Medis & & \\
1. Salah & 56 & $56 \%$ \\
2. Benar & 44 & $44 \%$ \\
\hline Yang Bukan Kegunaan Rekam & & \\
Medis & & \\
1. Salah & 64 & $64 \%$ \\
2. Benar & 36 & $36 \%$ \\
\hline Yang Dimaksud Dengan Rekam & & \\
Medis Pasif & & \\
1. Salah & $54 \%$ \\
2. Benar & 38 & $56 \%$ \\
\hline Yang Dimaksud Dengan Rekam & & \\
Medis Aktif & & \\
1. Salah & & \\
2. Benar & & \\
\hline
\end{tabular}




\begin{tabular}{lcc}
\hline \multicolumn{1}{c}{ Pertanyaan } & Jumlah & Persentase \\
\hline $\begin{array}{l}\text { Rekam Medis Bersifat } \\
\text { Rahasia,Karena: }\end{array}$ & \\
1. Salah & 65 & $65 \%$ \\
2. Benar & 35 & $35 \%$ \\
\hline Kegunaan Rekam Medis Dilihat & & \\
Dari Berbagai Aspek, Antara & & \\
Lain & 38 & $38 \%$ \\
1. Salah & 62 & $62 \%$ \\
2. Benar & & \\
\hline Pendokumentasian Yang Sangat & & \\
Tepat Berguna Bagi Pihak & 29 & $71 \%$ \\
1. Salah & 71 & \\
2. Benar & & \\
\hline
\end{tabular}

Pengetahuan responden dikategorikan menjadi berpengetahuan baik dan kurang baik. Pengkategorian menggunakan kriteria median. Jika skor pengetahuan lebih besar atau sama dengan median (6), dikategorikan berpengetahuan baik, jika skor pengetahuan lebih kecil atau sama dengan median (6), dikategorikan berpengetahuan kurang baik, seperti yang terlihat pada tabel 3 .

Tabel 3. Distribusi Responden menurut Pengetahuan terhadap Pengisian Berkas Rekam Medis di Rumah Sakit Harum Sisma Medika Jakarta Timur Tahun 2012

\begin{tabular}{lcc}
\hline \multicolumn{1}{c}{ Pengetahuan } & Jumlah & Persentase \\
\hline Baik & 50 & $50 \%$ \\
Buruk & 50 & $50 \%$ \\
\hline Total & 100 & $100 \%$ \\
\hline
\end{tabular}

\section{GambaranKeterampilan}

Gambaran keterampilan responden diukur menggunakan tiga pertanyaan. Berikut adalah rincian jawaban responden dapat dilihat pada tabel 4 .

Tabel 4. Distribusi Pertanyaan dan Jawaban Keterampilan Responden tentang Rekam Medis

\begin{tabular}{lcc}
\hline \multicolumn{1}{c}{ Pertanyaan } & Jumlah & Persentase \\
\hline $\begin{array}{l}\text { Apakah Anda Selalu Mengisi } \\
\text { Discarge Planning }\end{array}$ & \\
1. Salah & 36 & $36 \%$ \\
2. Kadang - Kadang & - & - \\
3. Benar & 64 & 64 \\
\hline Apakah Discarge Planning & & \\
Selalu Diisi Setiap Tindakan & & \\
1. Salah & 66 & - \\
2. Kadang - Kadang & - & $34 \%$ \\
3. Benar & 34 & \\
\hline
\end{tabular}

\begin{tabular}{|c|c|c|c|}
\hline \multicolumn{2}{|r|}{ Pertanyaan } & Jumlah & Persentase \\
\hline \multicolumn{4}{|c|}{$\begin{array}{l}\text { Dengan Cara Apa Anda } \\
\text { Menginput Data }\end{array}$} \\
\hline 1. & Salah & 68 & $68 \%$ \\
\hline 2. & Kadang - Kadang & - & - \\
\hline 3. & Benar & 32 & $32 \%$ \\
\hline
\end{tabular}

Keterampilan responden dikategorikan menjadi keterampilan baik dan buruk.Pengkategorian menggunakan kriteria median. Jika skor ketrampilan lebih besar atau sama dengan median (2), dikategorikan keterampilan baik, jika skor pengetahuan lebih kecil dari median (2), dikategorikan berketerampilan buruk, seperti yang terlihat pada tabel 5 .

Tabel 5. Distribusi Responden menurut Keterampilan terhadap Pengisian Berkas Rekam Medis di Rumah Sakit Harum Sisma Medika Jakarta Timur Tahun 2012

\begin{tabular}{lcc}
\hline \multicolumn{1}{c}{ Keterampilan } & Jumlah & Persentase \\
\hline Baik & 68 & $68 \%$ \\
Buruk & 32 & $32 \%$ \\
Total & 100 & $100 \%$ \\
\hline
\end{tabular}

\section{Gambaran Mutu}

Dari hasil analisis dalam Mutu yang dikategorikan menjadi 2 yaitu baik dan buruk, didapat jumlah responden yang berpengetahuan Baik berjumlah 56 responden (56\%), dan yang berpengetahuan Buruk berjumlah 44 responden (44\%).

Tabel 6. Distribusi Repsonden menurut Mutu Rekam Medis di Rumah Sakit Harum Sisma Medika Jakarta Timur Tahun 2012

\begin{tabular}{lcc}
\hline \multicolumn{1}{c}{ Mutu } & Jumlah & Persentase \\
\hline Baik & 56 & $56 \%$ \\
Buruk & 44 & $44 \%$ \\
Total & 100 & $100 \%$ \\
\hline
\end{tabular}

Gambaran Kelengkapan Pengisian Berkas Rekam Medis

Gambaran kelengkapan dalam pengisian berkas rekam medis responden diukur menggunakan 3 pertanyaan.Berikut adalah rincian jawaban responden dapat dilihat pada tabel 7 .

Tabel 7. Distribusi Pertanyaan dan Jawaban Kelengkapan dalam Pengisian Berkas Rekam Medis Responden 


\begin{tabular}{lcc}
\hline \multicolumn{1}{c}{ Pertanyaan } & Jumlah & Persentase \\
\hline $\begin{array}{l}\text { Apakah anda mengisi keadaan } \\
\text { penderita, grafik, pemberian } \\
\text { obat - obatan, pemberian } \\
\text { cairan, tanggal/waktu : }\end{array}$ & \\
1. Salah & 22 & \\
2. Kadang - Kadang & 4 & $22 \%$ \\
3. Benar & 74 & $4 \%$ \\
Apakah Anda Mengisi Catatan & & $74 \%$ \\
Mengenai Kemajuan Dan & & \\
Kemunduran Pasien & & \\
1. Salah & 17 & $17 \%$ \\
2. Kadang - Kadang & 6 & $6 \%$ \\
3. Benar & 77 & $77 \%$ \\
\hline Apakah Anda Memereiksa & & \\
Kembali Hasil Pemeriksaan & & \\
1. Salah & 17 & $6 \%$ \\
2. Kadang - Kadang & 6 & \\
3. Benar & 77 & \\
\hline
\end{tabular}

Kelengkapan dalam pengisian berkas rekam medis responden dikategorikan baik dan buruk. Dengan pengkategorian diambil dari nilai median. Jika skor $>6$ atau sama dengan 6 maka bisa dinyatakan kelengkapan dalam pengisian berkas rekam medis adalah baik, namun jika skor $<6$ dan atau sama dengan 6 maka dinyatakan kelengkapan dalam pengisian berkas rekam medis dinyatakan buruk, seperti tertera pada tabel 8 .

Tabel 8. Distribusi Pertanyaan dan Jawaban Kelengkapan dalam Pengisian Berkas Rekam Medis Responden

\begin{tabular}{|c|c|c|}
\hline $\begin{array}{c}\text { Kelengkapan } \\
\text { Berkas }\end{array}$ & Jumlah & Persentase \\
\hline Baik & 100 & $100 \%$ \\
\hline Buruk & - & - \\
\hline Total & 100 & $100 \%$ \\
\hline
\end{tabular}

Gambaran Ketepatan Waktu Pengisian Berkas Rekam Medis

Gambaran kelengkapan dalam pengisian berkas rekam medis responden diukur menggunakan 2 pertanyaan.Berikut adalah rincian pertanyaan dan jawaban responden dapat dilihat pada tabel 9.

Tabel 9. Distribusi Pertanyaan dan Jawaban Ketepatan Waktu dalam Pengisian Berkas Rekam Medis

\begin{tabular}{lcc}
\hline \multicolumn{1}{c}{ Pertanyaan } & Jumlah & Persentase \\
\hline $\begin{array}{l}\text { Berapa Lama Waktu Yang } \\
\text { Digunakan Untuk Membuat } \\
\text { Resume Keperawatan }\end{array}$ & & \\
1. Salah & 54 & $54 \%$ \\
2. Kadang - Kadang & 1 & $1 \%$
\end{tabular}

\begin{tabular}{|c|c|c|c|}
\hline & Pertanyaan & Jumlah & Persentase \\
\hline 3. & Benar & 45 & $45 \%$ \\
\hline \multicolumn{4}{|c|}{$\begin{array}{l}\text { Berapa Lama Waktu } \\
\text { Pengembalian Berkas Keruang } \\
\text { Rekam Medis }\end{array}$} \\
\hline 1. & Salah & 47 & $47 \%$ \\
\hline 2. & Kadang - Kadang & - & - \\
\hline 3. & Benar & 53 & $53 \%$ \\
\hline
\end{tabular}

Ketepatan waktu dalam pengisian berkas rekam medis responden dikategorikan baik dan buruk. Dengan pengkategorian diambil dari nilai median. Jika skor $>2$ atau sama dengan 2 maka bisa dinyatakan ketepatan dalam pengisian berkas rekam medis adalah baik, namun jika skor $<2$ dan atau sama dengan 2 maka dinyatakan ketepatan waktu dalam pengisian berkas rekam medis dinyatakan buruk. Hal tersebutdapat dilihat pada tabel 10.

Tabel 10. Distribusi Responden menurut Ketepatan Waktu dalam Pengisian Berkas Rekam Medis di Rumah Sakit Harum Sisma Medika Jakarta Timur Tahun 2012

\begin{tabular}{lcc}
\hline Ketepatan Waktu & Jumlah & Persentase \\
\hline Baik & 76 & $76 \%$ \\
Buruk & 24 & $24 \%$ \\
Total & 100 & $100 \%$ \\
\hline
\end{tabular}

\section{Gambaran Keakuratan}

Gambaran keakuratan dalam pengisian berkas rekam medis responden diukur menggunakan 4 pertanyaan. Berikut adalah rincian pertanyaan dan jawaban responden dapat dilihat pada tabel 11 .

Tabel 11. Distribusi Pertanyaan dan Jawaban Keakuratan dalam Pengisian Berkas Rekam Medis

\begin{tabular}{lcc}
\hline \multicolumn{1}{c}{ Pertanyaan } & Jumlah & Persentase \\
\hline $\begin{array}{l}\text { Apakah Anda Meneliti Identitas } \\
\text { Pasien Sesuai Dengan Waktu } \\
\text { Masuk Untuk Dirawat }\end{array}$ & \\
1. Salah & 15 & \\
2. Kadang - Kadang & 21 & $15 \%$ \\
3. Benar & 64 & $64 \%$ \\
\hline Apakah Anda Melihat Catatan & & \\
Pemeriksaan Sesuai Dengan & & \\
Instruksi Dokter & - & \\
1. Salah & 32 & \\
2. Kadang - Kadang & 68 & $68 \%$ \\
3. Benar & & \\
\hline Apakah Anda Melihat Catatan & \\
Diagnosis Sesuai Dengan Hasil & & \\
Pemeriksaan Pasien &
\end{tabular}




\begin{tabular}{llcc}
\hline \multicolumn{1}{c}{ Pertanyaan } & Jumlah & Persentase \\
\hline 1. $\quad$ Salah & 13 & $13 \%$ \\
2. Kadang - Kadang & 32 & $32 \%$ \\
3. $\quad$ Benar & 55 & $55 \%$ \\
\hline \multicolumn{2}{l}{ Apakah Anda Meneliti Tanggal } \\
Dan Waktu Pemeriksaan \\
1. Salah & 18 & \\
2. Kadang - Kadang & 21 & $21 \%$ \\
3. & Benar & 61 & $61 \%$ \\
\hline
\end{tabular}

Keakuratan dalam pengisian berkas rekam medis responden dikategorikan baik dan buruk. Dengan pengkategorian diambil dari nilai median. Jika skor $>6$ atau sama dengan 8 maka bisa dinyatakan keakuratan dalam pengisian berkas rekam medis adalah baik, namun jika skor $<6$ dan atau sama dengan 6 maka dinyatakan keakuratan dalam pengisian berkas rekam medis dinyatakan buruk. Hal tersebutdapatdilihat pada tabel 12 .

Tabel 12. Distribusi Responden menurut Keakuratan dalam Pengisian Berkas Rekam Medis di Rumah Sakit Harum SismaMedikaJakarta TimurTahun 2012

\begin{tabular}{lcc}
\hline \multicolumn{1}{c}{ Keakuratan } & Jumlah & Persentase \\
\hline Baik & 62 & $62 \%$ \\
Buruk & 38 & $38 \%$ \\
Total & 100 & 100 \\
\hline
\end{tabular}

\section{Gambaran PemenuhanAspekHukum}

Gambaran pemenuhan aspek hukum dalam pengisian berkas rekam medis responden diukur menggunakan 9 pertanyaan.Berikut adalah rincian pertanyaan dan jawaban responden dapat dilihat pada tabel 13.

Tabel 13 Distribusi Pertanyaan dan Jawaban Pemenuhan Aspek Hukum dalam Pengisian Berkas Rekam Medis

\begin{tabular}{lcc}
\hline \multicolumn{1}{c}{ Pertanyaan } & Jumlah & Persentase \\
\hline $\begin{array}{l}\text { Apakah Anda Melakukan } \\
\text { Penulisan Tidak Dengan Pensil }\end{array}$ & \\
1. Salah & 24 & $24 \%$ \\
2. Kadang - Kadang & 9 & $9 \%$ \\
3. Benar & 67 & $67 \%$ \\
\hline Apakah Anda Melakukan & & \\
Penghapusan & 18 & $18 \%$ \\
1. Salah & 19 & $19 \%$ \\
2. Kadang - Kadang & 63 & $63 \%$ \\
3. Benar & & \\
\hline Apakah Anda Melakukan & & \\
Coretan Atau Perbaikan Tulisan & 31 & $31 \%$ \\
1. Salah & 49 & $20 \%$ \\
2. Kadang - Kadang & 20 & \\
3. Benar &
\end{tabular}

\begin{tabular}{|c|c|c|}
\hline Pertanyaan & Jumlah & Persentase \\
\hline $\begin{array}{l}\text { Apakah Anda Melakukan } \\
\text { Pembetulan Sesuai Dengan } \\
\text { Prosedur Yakni Ada Tanggal } \\
\text { Dan Tanda Tangan }\end{array}$ & & \\
\hline 1. Salah & 5 & $5 \%$ \\
\hline 2. Kadang - Kadang & 6 & $6 \%$ \\
\hline 3. Benar & 89 & $89 \%$ \\
\hline \multicolumn{3}{|l|}{$\begin{array}{l}\text { Apakah Anda Melihat Ada } \\
\text { Nama Dokter }\end{array}$} \\
\hline 1. Salah & 18 & $18 \%$ \\
\hline 2. Kadang - Kadang & 7 & $7 \%$ \\
\hline 3. Benar & 75 & $75 \%$ \\
\hline \multicolumn{3}{|l|}{$\begin{array}{l}\text { Apakah Anda Mengecek } \\
\text { Lembar Persetujuan Tindakan } \\
\text { Medis }\end{array}$} \\
\hline 1. Salah & 17 & $17 \%$ \\
\hline 2. Kadang - Kadang & 2 & $2 \%$ \\
\hline 3. Benar & 81 & $81 \%$ \\
\hline \multicolumn{3}{|l|}{$\begin{array}{l}\text { Apakah Anda Menulis Identitas } \\
\text { Pasien Sesuai Dengan Waktu } \\
\text { Masuk Untuk Dirawat }\end{array}$} \\
\hline 1. Salah & 40 & $40 \%$ \\
\hline 2. Kadang - Kadang & - & - \\
\hline 3. Benar & 60 & $60 \%$ \\
\hline \multicolumn{3}{|l|}{$\begin{array}{l}\text { Apa Ada Menulis Nama } \\
\text { Perawat Yang Menangani } \\
\text { Pasien }\end{array}$} \\
\hline 1. Salah & 32 & $32 \%$ \\
\hline 2. Kadang - Kadang & - & - \\
\hline 3. Benar & 68 & $68 \%$ \\
\hline \multicolumn{3}{|l|}{$\begin{array}{l}\text { Apakah Anda Mengisi Tanggal } \\
\text { Dan Waktu Tindakan }\end{array}$} \\
\hline 1. Salah & 42 & $42 \%$ \\
\hline 2. Kadang-Kadang & - & - \\
\hline 3. Benar & 58 & $58 \%$ \\
\hline
\end{tabular}

Pemenuhan aspek hukum dalam pengisian berkas rekam medis responden dikategorikan baik dan buruk. Dengan pengkategorian diambil dari nilai median. Jika skor $>12,5$ atau sama dengan 12,5 maka bisa dinyatakan pemenuhan aspek hukum dalam pengisian berkas rekam medis adalah baik, namun jika skor $<12,5$ dan atau sama dengan 12,5 maka dinyatakan pemenuhan aspek hukum dalam pengisian berkas rekam medis dinyatakan buruk. Hal tersebutdapatdilihatpadatabel 14 .

Tabel 14. Distribusi Responden menurut Pemenuhan Aspek Hukum dalam Pengisian Berkas Rekam Medis di Rumah Sakit Harum Sisma Medika Jakarta Timur Tahun 2012

\begin{tabular}{lcc}
\hline \multicolumn{1}{c}{ Keakuratan } & Jumlah & Persentase \\
\hline Baik & 50 & $50 \%$ \\
Buruk & 50 & $50 \%$ \\
Total & 100 & $100 \%$ \\
\hline
\end{tabular}




\section{Analisis Bivariat}

Analisis bivariat dilakukan untuk melihat hubungan antara variabel bebas yaitu karakteristik responden (usia dan lama masa kerja) terhadap variabel terikat yaitu mutu. Uji statistik yang digunakan adalah Chi Square. Derajat kepercayaan yang digunakan adalah $95 \%(\mathrm{a}=0,05)$. Jika $\mathrm{P}$ value lebih kecil dari a $(\mathrm{p}<0,05)$, artinya terdapat hubungan yang bermakna(signifikan) antara kedua variabel yang diteliti, sedangkan bila $\mathrm{P}$ value lebih besar dari a $(p>0,05)$, artinya tidak terdapat hubungan yang bermakna (signifikan) antara kedua variabel yang diteliti.

Tabel 15. Distribusi Responden menurut Usia Responden dan Mutu Berkas rekam Medis

\begin{tabular}{|c|c|c|c|c|c|c|c|}
\hline \multirow{3}{*}{ Usia } & \multicolumn{4}{|c|}{ Mutu } & \multirow{2}{*}{\multicolumn{2}{|c|}{ Total }} & \multirow{3}{*}{$\begin{array}{c}P \\
\text { Value }\end{array}$} \\
\hline & \multicolumn{2}{|c|}{ Buruk } & \multicolumn{2}{|c|}{ Baik } & & & \\
\hline & $\mathbf{N}$ & $\%$ & $\mathbf{N}$ & $\%$ & $\mathbf{N}$ & $\%$ & \\
\hline $\begin{array}{l}<30 \\
\text { tahun }>= \\
30 \text { tahun }\end{array}$ & 3719 & 55,460 & 2816 & 44,640 & 6535 & $\begin{array}{l}100 \\
100\end{array}$ & 0,966 \\
\hline $\mathrm{Jml}$ & 56 & 56 & 44 & 44 & 100 & 100 & \\
\hline
\end{tabular}

Hasil analisis hubungan antara usia dan mutu dalam pengisian berkas rekam medis dalm kategori baik pada usia $<30$ tahun sebanyak $28(28 \%)$, dan usia $>30$ tahun sebanyak 16(16\%). Hasil uji statistik diperoleh nilai $\mathrm{p}=0,966$ maka disimpulkan ada perbedaan proporsi kejadian mutu dalam pengisian berkas rekam medis antara yang berusia $<30$ tahun dan $>30$ tahun (tidak ada hubungan yang signifikan antara usia dan mutu dalam pengisian berkas rekam medis). Dari hasil analisa diperoleh pula nilao $\mathrm{OR}=1,113$ artinya usia $<30$ tahun mempunyai peluang 1,907 kali untuk mempunyai mutu dalam pengisian berkas rekam medis dibandingkan $>30$ tahun.

Tabel 16. Distribusi Responden menurut Lama Masa Kerja Responden dan Mutu Berkas Rekam Medis

\begin{tabular}{|c|c|c|c|c|c|c|c|}
\hline \multirow{3}{*}{$\begin{array}{l}\text { Lama } \\
\text { Masa } \\
\text { Kerja }\end{array}$} & \multicolumn{4}{|c|}{ Mutu } & \multirow{2}{*}{\multicolumn{2}{|c|}{ Total }} & \multirow{3}{*}{$\begin{array}{c}\mathbf{P} \\
\text { Value }\end{array}$} \\
\hline & \multicolumn{2}{|c|}{ Buruk } & \multicolumn{2}{|c|}{ Baik } & & & \\
\hline & $\mathbf{N}$ & $\%$ & $\mathbf{N}$ & $\%$ & $\mathbf{N}$ & $\%$ & \\
\hline $\begin{array}{l}<5 \text { tahun }> \\
=5 \text { tahun }\end{array}$ & 2828 & 2828 & 2915 & 2915 & 5644 & 100100 & 0,164 \\
\hline $\mathrm{Jml}$ & 56 & 56 & 44 & 44 & 100 & 100 & \\
\hline
\end{tabular}

Hasil analisis hubungan antara lama masa kerja dan mutu dalam pengisianberkasrekam medis pada masa kerja $<5$ tahun sebanyak 29 (29\%), dan 15(15\%). Pada hasil uji statistik diperoleh nilai $\mathrm{p}=0,164$ maka disimpulkan ada perbedaan proporsi kejadian mutu dalam pengisian berkas rekam medis antara yang berusia $<5$ tahun dan $>5$ tahun (tidak ada hubungan yang signifikan antara lama mas kerja dan mutu dalam pengisian berkas rekam medis). Dari hasil analisa diperoleh pula nilao $\mathrm{OR}=0,517$ artinya usia $<$ tahun mempunyai peluang 0,517 kali untuk mempunyai mutu dalam pengisian berkas rekam medis dibandingkan $>5$ tahun.

Tabel 17. Distribusi Responden menurut Pengetahuan Responden dan Mutu Berkas Rekam Medis

\begin{tabular}{|c|c|c|c|c|c|c|c|}
\hline \multirow{3}{*}{ Pengetahuan } & \multicolumn{4}{|c|}{ Mutu } & \multirow{2}{*}{\multicolumn{2}{|c|}{ Total }} & \multirow{3}{*}{$\begin{array}{c}\mathbf{P} \\
\text { Value }\end{array}$} \\
\hline & \multicolumn{2}{|c|}{ Buruk } & \multicolumn{2}{|c|}{ Baik } & & & \\
\hline & $\mathbf{N}$ & $\%$ & $\mathbf{N}$ & $\%$ & $\mathbf{N}$ & $\%$ & \\
\hline Buruk Baik & 3416 & 3416 & 2228 & 2228 & 5644 & $\begin{array}{l}100 \\
100\end{array}$ & 0,027 \\
\hline Jumlah & 50 & 50 & 50 & 50 & 100 & 100 & \\
\hline
\end{tabular}

Hasil analisis hubungan antara pengetahuan dan mutu dalam pengisian berkas rekam medis dalam kategori baik sebanyak 22(22\%), dan pengetahuan buruk sebanyak 28(28\%). Hasil uji statistik diperoleh nilai $\mathrm{p}=0,027$ maka disimpulkan ada persamaan proporsi kejadian mutu dalam pengisian berkas rekam medis antara yang berpengetahuan baik dan buruk (terjadi angka yang signifikan antara pengetahuan dan mutu dalam pengisian berkas rekam medis). Dari hasil analisa diperoleh pula nilai $\mathrm{OR}=2,705$ artinya pengetahuan yang baik mempunyai peluang 2,705 kali untuk mempunyai mutu dalam pengetahuan rekam medis dibandingkan dengan yang berpengetahuan buruk.

Tabel 18. Distribusi Responden menurut Keterampilan Responden dan Mutu Berkas Rekam Medis

\begin{tabular}{|c|c|c|c|c|c|c|c|}
\hline \multirow{3}{*}{$\begin{array}{c}\text { Keteram- } \\
\text { pilan }\end{array}$} & \multicolumn{4}{|c|}{ Mutu } & \multirow{2}{*}{\multicolumn{2}{|c|}{ Total }} & \multirow{3}{*}{$\begin{array}{c}\mathbf{P} \\
\text { Value }\end{array}$} \\
\hline & \multicolumn{2}{|c|}{ Buruk } & \multicolumn{2}{|c|}{ Baik } & & & \\
\hline & $\mathbf{N}$ & $\%$ & $\mathbf{N}$ & $\%$ & $\mathbf{N}$ & $\%$ & \\
\hline $\begin{array}{l}\text { Buruk } \\
\text { Baik }\end{array}$ & 3830 & 3830 & 1814 & 1814 & 5644 & 100100 & 1,000 \\
\hline Jumlah & 68 & 57 & 32 & 32 & 100 & 100 & \\
\hline
\end{tabular}

Hasil analisis hubungan antara keterampilan dan mutu dalam pengisian berkas rekam medis dalm kategori buruk sebesar 18(18\%), dan berpengetahuan baik sebanyak 14(14\%). Hasil uji statistik diperoleh nilai $\mathrm{p}=1,000$ maka disimpulkan ada perbedaan proporsi kejadian mutu dalam pengisian berkas rekam medis antara yang keterampilan buruk dan baik (tidak ada hubungan yang signifikan antara keterampilan dan mutu dalam pengisian berkas 
rekam medis). Dari hasil analisa diperoleh pula nilao $\mathrm{OR}=0,985$ artinya keterampilan buruk pada perawat mempunyai peluang 0,985 kali untuk menyebabkan buruknya mutu dalam pengisian berkas rekam medis dibandingkan perawat yang berketerampilan baik.

\section{PEMBAHASAN}

\section{Keterbatasan Kualitas Data}

Pengumpulan data dengan menggunakan kuesioner yang diisi oleh responden itu sendiri bersifat subyektif, sehingga kebenaran data tergantung kepada keseriusan dan kejujuran responden dalam mengisi kuesioner, selain itu, kuesioner yang diajukan mencakup pengetahuan dan keterampilan pada pengisian berkas rekam medis terhadap mutu Rekam Medis yang mereka ketahui.

\section{Keterbatasan Variabel Penelitian}

Terdapat banyak faktor yang berhubungan dengan pengetahuan keterampilan dalam mutu rekam medis perawat, tetapi karena keterbatasan yang ada maka hanya dipilih beberapa variabel saja. Pemilihan variabel didasarkan pada teori dan penelitian sebelumnya, walaupun demikian masih ada variabelvariabel lain yang masih bisa diteliti yang berkaitan dengan Mutu Rekam Medis.

\section{Keterbatasan Instrumen Penelitian}

Instrumen penelitian secara keseluruhan adalah kuesioner yang dibuat oleh peneliti sendiri. Kelemahan dari instrumen menggunakan kuesioner adalah pertanyaan pada kuesioner berbentuk tertutup, terstruktur, sehingga tidak membuka peluang dikemukakan jawaban lain oleh responden. Alasan-alasan yang lebih mendalam tidak dapat ditemukan kaena tidak hanya intrumen yang memungkinkan jawaban menjadi lebih mendalam. Dengan pengumpulan data melalui kuesioner terdapat kelemahan tersendiri, dikarenakan kuesioner dengan pertanyaan yang sangat terbatas dan diisi langsung oleh responden yang kemungkinan berbeda persepsi dan jawaban yang mungkin cenderung kepada jawaban ideal yang tidak sesuai dengan kondisi yang sebenarnya.

Hubungan antara Karakteristik Responden (Usia dan Lama Kerja) terhadap Mutu Rekam Medis
Karakteristik responden pada penelitian ini terdiri dari usia, dan lama masa kerja. Dari 100 responden terdapat 67 (67\%) responden pada usia $<30$ tahun, pada usia $>30$ tahun berjumlah 34 responden (34\%). Penelitian ini menggambarkan tidak adanya hubungan yang bermakna antara usia terhadap mutu rekam medis. (p value $=0,966)$ dan odds Ratio (OR) sebesar 1,113. Dilihat dari hasil diatas dapat disimpulkan bahwa kemungkinan semakin bertambahnya usia,maka ingatan dan ketelitian dalam mengerjakan sesuatu semakin menurun, dan pada usia $>30$ tahun kemungkinan melakukan kesalahan $1 \mathrm{x}$ lebih sering dibandingkan pada responden yang berusia $<30$ tahun.

Pada lama masa kerja responden yang terbanyak adalah $<5$ tahun berjumlah 54 responden (54\%), dan masa kerja $>5$ tahun berjumlah 36 responden (36\%). Hasil penelitian ini menggambarkan bahwa tidak adanya hubungan yang bermakna antara masa lama kerja responden dengan mutu rekam medis ( $\mathrm{p}$ value $=0,614)$ dan Odds Ratio (OR) sebesar 0,517. maka bisa disimpulkan hasil penelitian tidak sesuai dengan apa yang dikatakan oleh (Notoatmodjo,2003) bahwa semakin lama seseorang bekerja semakin baik pula dalam memberikan pelayanan, baik dalam medis dan pendokumentasian. Dari hasil yang didapat, bisa diambil kemungkinan bahwa dilihat dari kemajuan ilmu pengetahuan dan teknologi,kemungkinan responden yang masa kerjanya $<5$ tahun sudah mengikuti perkembangan tersebut dan menerapkannya di tempat kerja mereka,sedangkan responden yang bekerja $>5$ tahun kemungkinan tidak mengikuti perkembangan dan kemajuan ilmu pengetahuan tentang rekam medis dan kemungkinan untuk melakukan kesalahan sebesar 0,517 dibandingkan dengan responden yang lama masa kerjanya $>5$ tahun.

\section{Hubungan antara Pengetahuan Responden dan Mutu Rekam Medis}

Pengetahuan responden pada penelitian ini bagi menjadi dua kategori Baik dan Buruk. Dari 100 responden terdapat $50(50 \%)$ berpengetahuan Baik, dan $50(50 \%)$ responden berpengetahuan Buruk, dimana hasil ini didapat dari jawaban kuesioner dari pertanyaan tentang pengetahuan berjumlah 8 pertanyaan. Penelitian ini menggambarkan adanya hubungan yang bermakna antara pengetahuan terhadap mutu rekam medis. ( $\mathrm{p}$ value $=0,277)$ dan 
odds Ratio (OR) sebesar 2,705. Sebagian besar pengetahuan seseorang diperoleh dari melalui indera pendengaran (telinga), dan indera penglihatan (mata). (Notoatmodjo, 2005) jadi dengan kata lain, pengetahuan responden dapat baik jika mereka sering bertukar pendapat dan membaca, jadi kemungkinan dari hasil penelitian ini adalah bahwa 50 responden berpengetahuan Baik dikarenakan peka terhadap kemajuan ilmu pengetahuan dan teknologi tentang rekam medis yang berkembang pada saat sekarang dibandingkan 50 responden yang berpengetahuan Buruk, serta responden yang berpengetahuan Buruk kemungkinan melakukan kesalahan sebesar $2 x$ lebih besar dibandingkan responden yang berpengetahuan Baik.

\section{Hubungan antara Keterampilan Responden dan Mutu Rekam Medis}

Keterampilan responden pada penelitian ini bagi menjadi dua kategori Baik dan Buruk. Dari 100 responden terdapat $68(68 \%)$ berketerampilan Baik, dan 32 (32\%) responden berketerampilan Buruk. Penelitian ini menggambarkan tidak adanya hubungan yang bermakna antara keterampilan responden dalam pengisian berkas rekam medis terhadap mutu rekam medis. ( $\mathrm{p}$ value $=1,000)$ dan odds Ratio (OR) sebesar 0,985. Hal itu disebabkan kemungkinan dari ketelitian dari responden dalam mengisi berkas rekam medis sudah baik.

Keterampilan/Pengetahuan pegawai terdiri dari kemampuan potensi dan kemampuan reality. Artinya, pegawai yang memiliki kemampuan diatas rata-rata dengan pendidikan atau pengetahuan memadai untuk menjalankan pekerjaan sehari-hari, maka ia akan lebih mudah mencapai kinerja(prestasi) yang diharapkan. Oleh karena itu, pegawai perlu ditempatkan pada pekerjaan yang sesuai dengan keahliannya (Ridwan,2008).

\section{SIMPULAN}

1. Karateristik jenis kelamin pada responden terbanyak pada Perempuan mencapai 95 responden (95\%) dan Laki-Laki berjumlah 5 repsonden (5\%).

2. Karateristik kelompok usia/umur responden yang paling banyak yaitu pada usia $<30$ tahun berjumlah 67 (67\%) responden dan paling sedikit $>30$ tahun 34 (34\%).
3. Karateristik Lama Masa Kerja $<5$ tahun berjumlah 54 (54\%) dan $>5$ tahun sebanyak $36(36 \%)$.

4. Hasil analisis bivariat berdasarkan hubungan Chi-Square karateristik usia/umur, lama masa kerja, terhadap Mutu Berkas Rekam Medis, hasil yang didapat adalah Usia/Umur ( $\mathrm{p}$ value $=0,966$ dan $\mathrm{OR}=1,113)$, Lama Masa Kerja ( $\mathrm{p}$ value = $0,164$ dan $\mathrm{OR}=0,517)$, karena nilai $\mathrm{P}$-value lebih besar dari 0.005 , maka dapat disimpulkan bahwa tidak mempergaruhi antara karateristik responden (Umur/Usia dan Lama Masa Kerja) terhadap mutu berkas rekam medis dirumah Sakit Harum Sisma Medika Jakarta Timur.

5. Pengetahuan responden yang berpengetahuan Baik sebanyak 50 orang $(50 \%)$ dan responden yang berpengetahuan buruk berjumlah 50 orang $(50 \%)$.

6. Faktor keterampilan responden yang berketerampilan baik berjumlah 68 (68\%), dan berketerampilan buruk berjumlah $32(32 \%)$.

7. Hasil bivariat berdasarkan hubungan ChiSquare antara pengetahuan terhadap Mutu Berkas Rekam Medis adalah dengan ( $\mathrm{p}$ value $=0,027$ dan $\mathrm{OR}=2,705$ ) menunjukkan bahwa antara pengetahuan dan mutu rekam medis terdapat hubungan yang bermakna karena mengingat $\mathrm{P}$-value lebih kecil dari 0,005 , dan dari hasil ini maka dapat disimpulkan bahwa pengetahuan responden dalam rekam medis sangat penting dalam mengetahui ukuran mutu rekam medis dengan benar. Sedangkan hasil dari keterampilan adalah ( $\mathrm{p}$ value $=1,000$ dan OR $=0,985$ ) karena nilai P-value lebih besar dari 0,005 maka hasil dapat dinyakan tidak adanya hubungan yang bermakna antara keterampilan dan mutu rekam medis, walau sebenarnya keterampilan sangat bisa mempunyai hubungan yang bermakna namun hasil dari penelitian ini menunjukkan hasil yang berbeda.

\section{DAFTAR PUSTAKA}

Alamsyah, Dedi. 2011. Manajemen Pelayanan Kesehatan. Yogyakarta: Nuha Medika.

Boekitman, Paul. 1996. Faktor-faktor yang berhubungan dengan Mutu Rekam Medis Instalasi Rawat Inap Penyakit Dalam RSUP Fatmawati. Jakarta: FKM UI 
Departemen Kesehatan R.I. 2008. Peraturanmenteri kesehatan no. 789a/Men.Kes/Per/2008 tentang Rekam Medis/Medical Record. Jakarta:Depkes RI.

Hatta, G., R. 1986. Peranan Rekam Medis dalam Tanggung Gugat Praktik Profesional Tenaga Kesehatan .Kumpulan Makalah Seminar Nasional dalam Kongresdan Rakernas I-III PORMIKI, 52 - 80.
Notoatmodjo, S. 2002. Ilmu kesehatan masyarakat (Prinsip-prinsipdasar). Jakarta: Rineka Cipta.

.2005. Ilmu kesehatan masyarakat (Prinsip-prinsipdasar). Jakarta: Rineka Cipta.

Kusuma, D., Fauziah, A. 2009. Informatika Kesehatan. Yogyakarta: Graha Mulia. 